\title{
IAMJ
}

INTERNATIONAL

AYURVEDIC

MEDICAL JOURNAL

Research Article

ISSN: 2320-5091

Impact Factor: 6.719

\section{A CLINICAL STUDY OF NIMBA PRATISARNEEYA KSHARA IN THE MANAGEMENT OF AYATHA-VRIDDHI W.S.R. TO POLYP}

\author{
Ritu Kumari', O. P. Dave ${ }^{2}$
}

${ }^{1}$ Assistant Professor, Dept. of Shalya Tantra, Ayujyoti Ayurvedic College \& Hospital, Jodhpuria, Sirsa, Haryana, India

${ }^{2}$ Professor \& H.O.D., Dept. of Shalya Tantra, Parul Institute of Ayurveda \& Research, Vadodara, Gujarat, India

Corresponding Author: ritusolnki2390@gmail.com

\section{https://doi.org/ $10.46607 /$ iamj0808122020}

(Published online: December 2020)

Open Access

(C) International Ayurvedic Medical Journal, India 2020

Article Received: 21/11/2020 - Peer Reviewed: 26/11/2020 - Accepted for Publication: 30/11/2020

Check for updates

\begin{abstract}
Aacharya Sushruta, the father of surgery has described few diseases under the heading of Kshudraroga, meaning that category of diseases that do not need major attention and the diseases that are simple and do not result in any complications or cause threat to life. Diseases like Charmkeela (warts) are not causing any noticeable discomfort but still their impact on body and mind is such that the individual suffering from such diseases falls into a state of distress. Aacharya Sushruta has been described a para-surgical procedure- Kshara Karma for the management of unwanted growths. Today advanced techniques and surgical procedures like sclerotherapy, laser therapy, cryosurgery, polypectomy etc have been innovated for the management of such type of unwanted growths which have their own disadvantages \& limitations. These unwanted growths have peculiar tendency of recurrence despite of their surgical removal. So, to avoid the surgical removal of unwanted growths and recurrence, the present work has been undertaken.
\end{abstract}

Keywords: Ayurveda, unwanted growths, Charmakeela, Pratisarneeya Kshara Karma.

\section{INTRODUCTION}

Unwanted Growths (Ayatha-Vriddhi) are skin growths which are a benign condition that consists of a lump of tissue projecting out from surrounding skin. The most common unwanted growths are warts, corn, skin tags, 
papilloma, polyps etc. Out of these disorders, in this present study only patients of Charmkeela Vyadhi (warts, papilloma) and visible polyps like nasal polyp, aural polyp have been taken for the clinical trial. Sushruta, the pioneer in the art of surgery, has described the concept of Charmakeela, its classification, symptomatology, etiological factors, pathology and specific treatment without its recurrence.

व्यानस्तु प्रकुपित: श्रेष्माणं परिगृह्य बहि: स्थिराणि | कीलवदर्शासी निर्वर्तयति, तानि चर्मकीलान्यर्शांसीत्याचक्षते। (सु०नि० 2/20)

Aggravated Vyanavaya taking along with Kapha produce externally firm and nail like growth is known as Charmakeela. The word 'Bahih' denotes Charmakeela or Arshas that are present other places than Guda Pradesh. Aacharya Sushruta has described a para-surgical procedure- Kshara Karma, for the management of Charmakeela (Su.Su.11/7). Kshara is alkaline in nature and it is one of the best para-surgical tools for the successful treatment of various surgical ailments as well as some medical disorders also. It is a type of chemical cauterization. It destroys the unhealthy tissues and promotes healing process. The plant Nimba is easily available and has anti-bacterial, anti-viral, anti-fungal \& anti-inflammatory properties. The reference of Nimba Kshara has been taken from Rajnighantu.

\section{Materials:}

- Literary material like Samhitas, Commentaries, Ayurvedic journals, Research papers, Internet providing sites, Manuscripts etc. to collect and compile the data related to this study.

- Patients suffering from unwanted growths like warts etc.

\section{Nimba Kshara}

- Standard accessory items like Shalaaka, 2-3 bowl in number, Gauze pieces, Cotton swabs, Gloves, Cotton, Bandage, Surgical blade.

- Nimbu Swarasa, Yastimadhu powder, Grit.

Methods:

1. Subjects: 50 patients were selected by keeping the signs and symptoms for unwanted growths (wart), irrespective of religion, occupation and socio-economic status for present study.

2. Source of Subjects: The patient suffering from Unwanted growths attending the O.P.D./ I.P.D. section of Shalya Tantra, University College of Ayurveda Hospital, Dr Sarvapalli Radhakrishnan Rajasthan Ayurveda University, Jodhpur, were randomly selected who fulfilling the inclusion and diagnostic criteria of study.

3. Sample size and Grouping:

\begin{tabular}{|l|l|l|l|l|l|l|}
\hline Groups & No. of pt. & Formulation & Route & Dose/Quantity & Time & Duration \\
\hline $\begin{array}{l}\text { Trial } \\
\text { group }\end{array}$ & 50 & $\begin{array}{l}\text { Nimba } \\
\text { Pratisarneeya } \\
\text { Kshara }\end{array}$ & $\begin{array}{l}\text { Local ap- } \\
\text { plication }\end{array}$ & $\begin{array}{l}\text { As per the size of } \\
\text { unwanted growth }\end{array}$ & $\begin{array}{l}\text { On alternate day, total 3 sittings } \\
\text { were given for Vakshatmaatra (upto } \\
\text { the time of 100 words) }\end{array}$ & 1 week \\
\hline
\end{tabular}

Follow up after Treatment - After the completion of treatment (1 week), all the patients were instructed to have regular follow up at 1 month (30 days). During this follow up period, patients were examined for the recurrence of either signs and symptoms of unwanted growths.

Kshara Karma procedure: Local application of Kshara which has mentioned in Sushruta Samhita Sutrasthana $11^{\text {th }}$ chapter "Ksharapakavidhi Adhyaaya".

\section{Selection Criteria:}

\section{Inclusion Criteria}

a) Patients between the age of 10-70 years.

b) Patients having unwanted growths concerned with cosmetic disorders of the skin.

\section{Exclusion Criteria}

a) Patients less than 10 years and more than 70 years.

b) Oedema all over the body.

c) Udar Rog and Raktapitta Rog.

d) Prolapse of genital organs.

e) Diseases originated with Marma, Sira, Snayu, Sandhi, Trunasthi, Sevni, Dhamani, Nabhi, Gal \& muscular atrophy. 
f) Patient with uncontrolled Hypertension/ Cardiac problem/Angina/ Diabetes Mellitus /Tuberculosis / Hepatitis and any systematic disorder.

g) Carcinoma

h) Pregnancy

i) HIV, VDRL, HBsAg

\section{Clinical Study:}

Selection of Problem - Among many diseases concerned with cosmetic values, Warts is a common disease known to us from thousands of years. Though it is considered as Kshudra Roga (Minor disease), has got a major importance as a cosmetic problem in the society. Today advanced techniques and surgical procedures like sclerotherapy, laser therapy, cryosurgery etc have been innovated for the management of such type of unwanted growths which have their own disadvantages \& limitations. Many of them are not affordable to common people and the chance of recurrence is still remaining after these approaches. Hence, there is a need to search better methods of management of these unwanted growths considering the above drawback. In such cases, the alternative better choice is Kshara
Karma. Practically it has proven its efficacy in reducing the post-operative pain and discomfort. It can be done in aged patients and even those who are unfit for surgery or not willing for surgery. It yields negligible rate of recurrence, cost effective, less pain, no bleeding, no infection, no application site reaction, simple and outdoor procedure, affordable to common people and requiring no need of hospitalization during treatment.

Therefore, there is a need for proper understanding of such problems of the society through Ayurvedic perspectives and to find some effective steps of management. So, in this trial, effort will be done to develop a cost-effective management for these unwanted growths.

Hence the present study is entitled as "A Clinical Study of Nimba Pratisarneeya Kshara In the Management of Ayatha-Vriddhi W.S.R. To Polyp".

\section{Aim \& Objectives:}

1. To achieve the factor of cosmetic and minimum scar orientated approaches.

2. To catalogue the role of Nimba Kshara in the management of unwanted growths.

\section{Criteria for Assessment:}

Table 1: Pain

\begin{tabular}{|l|l|}
\hline Findings & Grade \\
\hline No Pain & 0 \\
\hline Tolerable Pain & 1 \\
\hline Intolerable Pain & 2 \\
\hline
\end{tabular}

Table 2: Itching

\begin{tabular}{|l|l|}
\hline Findings & Grade \\
\hline No c/o itching & 0 \\
\hline Negligible itching occasionally in a day & 1 \\
\hline Frequent itching 4-6 hrs. Gap & 2 \\
\hline Continuous itching sensation & 3 \\
\hline
\end{tabular}

Table 3: Discharge

\begin{tabular}{|l|l|}
\hline Findings & Grade \\
\hline No discharge & 0 \\
\hline Very negligible discharge & 1 \\
\hline Scanty discharge & 2 \\
\hline Continuous flowing of profuse discharge & 3 \\
\hline
\end{tabular}

Table 4: Tenderness 


\begin{tabular}{|l|l|}
\hline No tenderness & 0 \\
\hline Patient winces & 1 \\
\hline Patient winces and withdraws affected part & 2 \\
\hline Patient does not allow to touch the part & 3 \\
\hline
\end{tabular}

Table 5: Burning Sensation

\begin{tabular}{|l|l|}
\hline Findings & Grade \\
\hline No c/o burning sensation & 0 \\
\hline Negligible burning sensation & 1 \\
\hline Occasional and tolerable burning sensation & 2 \\
\hline Intolerable burning sensation makes the patient uncomfortable & 3 \\
\hline
\end{tabular}

\section{Objective Criteria:}

- Physical appearance - Rough / smooth

- Size of unwanted growth

- Consistency - Hard / soft / spongy / granulated

- Colour - normal to skin colour / different to skin colour

- Removal/ stage of Clearance -

Table 6:

\begin{tabular}{|l|l|}
\hline Complete clearance & $100 \%$ \\
\hline \multirow{3}{*}{ Partial clearance } & $75 \% \&$ more \\
\hline No change & $50-75 \%$ \\
\hline & $25-50 \%$ \\
\hline
\end{tabular}

Table 7: Criteria for Total Effect of Therapy: For the assessment of the total effect of therapy following five categories has been taken into consideration:

\begin{tabular}{|l|l|}
\hline Complete Remission & $100 \%$ relief in sign and symptoms \\
\hline Marked Remission & $75 \%$ and more relief in sign and symptoms \\
\hline Moderate Remission & $50-74 \%$ relief in sign and symptoms \\
\hline Mild Remission & $25-49 \%$ relief in sign and symptoms \\
\hline No Response & $<25 \%$ relief in sign and symptoms \\
\hline
\end{tabular}

\section{Result:}

\section{Statistical Analysis}

The information was collected on the basis of observation made about various parameters were subjected to statistical analysis in terms of Mean, Standard Deviation (SD) and Standard Error (SE).

Graph Pad In Stat 3.1 software (Trial version) was used.
- Wilcoxon signed rank test - Nonparametric test for the case of two related samples or repeated measurement on a single set. It was used for the assessment of the improvement in subjective nonparametric symptoms of trial group. The result was calculated: Extremely significant $(\mathrm{p}<0.0001)$

Table 8: Effect of Therapy on Subjective Parameters in 50 patients of Trial group. 
Ritu Kumari $\mathcal{L}$ O. P. Dave: A Clinical Study Of Nimba Pratisarneeya Kshara In The Management Of Ayatha-Vriddhi W.S.R. To Polyp

\begin{tabular}{|l|l|l|l|l|l|l|l|l|}
\hline \multirow{2}{*}{ Parameters } & \multicolumn{2}{|l|}{ Mean } & Mean decrease & \% Relief & SD & SE & P value & S \\
\cline { 2 - 10 } & BT & AT & BT-AT & & & & & \\
\hline Pain & 1.48 & 0.04 & 1.44 & $97.29 \%$ & 0.19 & 0.027 & $<0.0001$ & ES \\
\hline Itching & 1.82 & 0.06 & 1.76 & $96.7 \%$ & 0.23 & 0.033 & $<0.0001$ & ES \\
\hline Discharge & 1.54 & 0.02 & 1.52 & $98.7 \%$ & 0.14 & 0.02 & $<0.0001$ & ES \\
\hline Tenderness & 2.12 & 0.12 & 2 & $94.3 \%$ & 0.32 & 0.46 & $<0.0001$ & ES \\
\hline Burning sensation & 1.8 & 0.04 & 1.76 & $97.7 \%$ & 0.19 & 0.027 & $<0.0001$ & ES \\
\hline
\end{tabular}

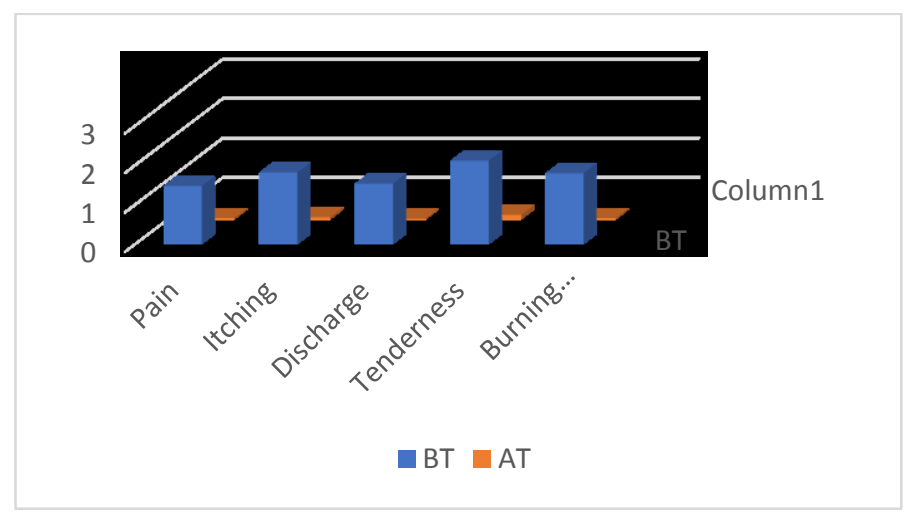

Table 9: Effect of Therapy on Physical appearance -

\begin{tabular}{|l|l|l|l|l|}
\hline Physical appearance & No. of Patients (BT) & No. of Patients (AT) & No. of Cured Patients (BT-AT) & \% Changes \\
\hline Rough & 34 & 09 & 25 & $73.5 \%$ \\
\hline Smooth & 16 & 05 & 11 & $68.75 \%$ \\
\hline
\end{tabular}

Table 10: Effect of Therapy on Size of Unwanted Growth -

\begin{tabular}{|l|l|l|l|l|}
\hline Size of U.G. (in mm) & No. of Patients (BT) & No. of Patients (AT) & No. of Cured Patients (BT-AT) & $\%$ Changes \\
\hline $2-3$ & 16 & 0 & 16 & $100 \%$ \\
\hline $4-5$ & 22 & 06 & 16 & $72.7 \%$ \\
\hline $6-7$ & 12 & 08 & 04 & $33.3 \%$ \\
\hline
\end{tabular}

Table 11: Effect of Therapy on Consistency -

\begin{tabular}{|l|l|l|l|l|}
\hline Consistency & No. of Patients (BT) & No. of Patients (AT) & No. of Cured Patients (BT-AT) & \% Changes \\
\hline Hard & 28 & 09 & 19 & $67.8 \%$ \\
\hline Soft & 12 & 02 & 10 & $83.3 \%$ \\
\hline Spongy & 04 & 01 & 03 & $75 \%$ \\
\hline Granulated & 06 & 02 & 04 & $66.6 \%$ \\
\hline
\end{tabular}

Table 12: Effect of Therapy on Colour -

\begin{tabular}{|l|l|l|l|l|}
\hline Colour & No. of Patients (BT) & No. of Patients (AT) & No. of Cured Patients (BT-AT) & \% Changes \\
\hline Normal to skin colour & 32 & 08 & 24 & $75 \%$ \\
\hline Different to skin colour & 18 & 06 & 12 & $66.6 \%$ \\
\hline
\end{tabular}

Table 13: Effect of Therapy on Stages of Clearance - 


\begin{tabular}{|l|l|l|}
\hline Stages of clearance & In \% & No. of Patients \\
\hline Complete & $100 \%$ & 36 \\
\hline Partial & $>75 \%$ & 05 \\
\hline & $50-75 \%$ & 04 \\
\hline No change & $25-50 \%$ & 02 \\
\hline
\end{tabular}

Table 14: In this present study, out of 48 patient Total effect of therapy in the reference of clearance of unwanted growths on the basis of subjective and objective parameters

\begin{tabular}{|l|l|l|l|}
\hline Therapy effect & $\%$ & No. of Patients & $\%$ of patients \\
\hline Complete Remission & $100 \%$ & 36 & $72 \%$ \\
\hline Marked Remission & $75 \%$ and more & 05 & $10 \%$ \\
\hline Moderate Remission & $50-74 \%$ & 04 & $8 \%$ \\
\hline Mild Remission & $25-49 \%$ & 02 & $4 \%$ \\
\hline No Response & $<25 \%$ & 01 & $2 \%$ \\
\hline
\end{tabular}

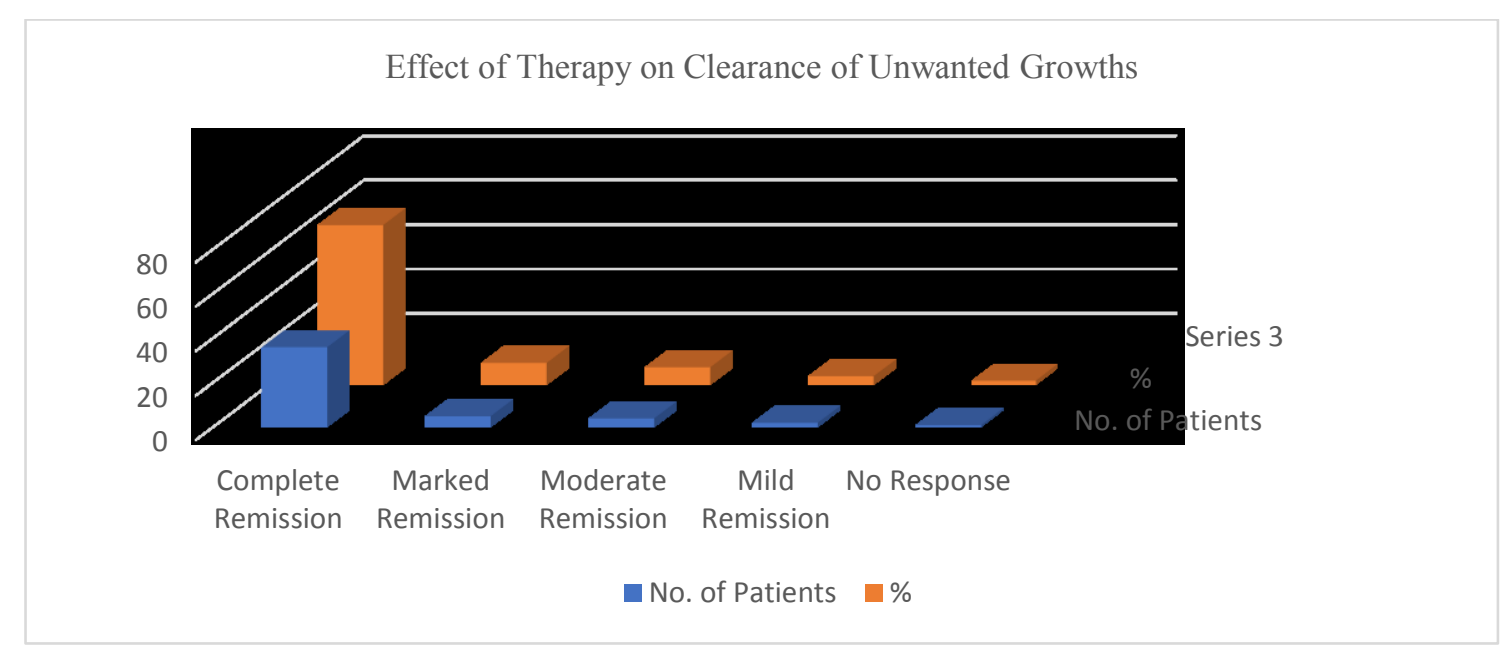

Probable mode of action of Pratisarneeya Kshara: Various type of treatment principles like Bheshaja, Shastra, Kshara Karma and Agni Karma for the management of Charmakeela are described by Aacharyas of Ayurveda. The selected unwanted growth i.e. wart is a disease that arise from epidermis layer of skin as a pinpoint black dots/mass. It has been repeatedly advocated by almost all the Aacharyas that diseases of skin like Charmakeela, Mashaka are better respond with the use of Pratisarneeya Kshara. The plant Nimba has Tikta Rasa which is Vishaghna and Kaphaghna, has Katu Vipaaka which is Vatakaphashaamak, Srotoshodhaka and it has anti-thrombotic, anti-neoplastic, antimicrobial, antioxidant and anti-inflammatory property. Kshara has properties like Chedana, Bhedana,
Lekhana, Shodhana, Ropana, Satambhana and Vatakaphahara, Krimighna, Srotovishodhaka for the eradication / removal of Charmakeela. It dissolves the bonding of Vata and Kapha in the process of Vilayana. Kshara acts through its Ksharan Karma and dissolves the unwanted growth. By its Kshanan property, it produces a sub lethal injury to abnormal tissue and corrosion of unwanted growths (क्षणनात् त्वङ्झांसादिहिंसनात्) and by its Kshapan property, expulsion of harmful substances from wound and cleanness of the wound (क्षपणं शोधनमभिप्रेतम्). 


\section{CONCLUSION}

Kshara Karma is a cost-effective Para surgical procedure which requires less pain, no bleeding, no infection, simple and outdoor procedure, affordable to common people and requiring no need of hospitalization during treatment, low recovery time with extremely patient's satisfaction. On the basis of the above made clinical observations it can be concluded that selected treatment protocol Nimba Pratisarneeya Kshara definitely possess all the qualities and properties as an ideal approach for unwanted growths \& it gives all the benefits radically up to the significant level and can be used as per the classical guidelines without any doubt.

\section{REFERENCES}

1. Sushruta, Sushruta Samhita Nidaanasthaana 13/44, with Ayurvedatatvaa Sandipika, Hindi Teeka by Kaviraj Ambikadatta Shastri, published by Chaukhamba Sanskrita Sansthan, Varanasi, reprint 2005, page 372 (ibid 1)

2. Ibid 1, Sushruta Samhita Nidanasthana 2/4 page 306.

3. Vagbhata, Ashtanga Hridayam Nidaana $7 / 57$, collected by Late Dr. Anna Moreshwer Kunte and Krishna Ramchandra Shastri Navre, edited by Pt. Hari Shadashiv Shastri, published by Choukhambha Surbharti Prakashana, reprint 2002, Page 482.

4. Ibid 1, Sushruta Samhita, Nidanasthana 2/20, Page 310

5. Ibid 1, Sushruta Samhita, Sootrasthana 11/7, Page 46

6. Ibid 1, Sushruta Samhita, Sootrasthana 25/3, Page 134

7. Ibid 1, Sushruta Samhita, Sootrasthana 12/10, Page 52

8. Dr. Inderdev Tripathi, Rajnighantu, Chapter- Misharkadi verga, shlok no. 57, Dravyaguna prakashika, hindi vyakhyaya, Krishandas Ayurved series 5, published by Chaukhambha krishandas akaadmi, Varaanasi, page no. 667

9. Aacharya Priyavrit Sharma, Dravyaguna Vigyaana, published by Chaukhamba Bharati Academy, Varaanasi, reprint edition 2018, Vol.2, Page 149

10. Ibid 1, Sushruta Samhita, Sootra Sthaana 11/33, Page 50

11. Ibid 1, Sushruta Samhita, Sootra Sthaana 11/4, Page 45

12. Ibid 1, Sushruta Samhita, Sootra Sthaana 11/26, Page 49

13. Ibid 1, Sushruta Samhita, Sootra Sthaana 11/5, Page 45

14. Ibid 1, Sushruta Samhita, Sootra Sthaana 11/7, Page 46

15. Ibid 1, Sushruta Samhita, Sootra Sthaana 11/9,30 Page 46,50
Source of Support: Nil

\section{Conflict of Interest: None Declared}

How to cite this URL: Ritu Kumari \& O. P. Dave: A Clinical Study Of Nimba Pratisarneeya Kshara In The Management Of Ayatha-Vriddhi W.S.R. To Polyp. International Ayurvedic Medical Journal \{online\} 2020 \{cited December, 2020\} Available from: http://www.iamj.in/posts/images/upload/5256_5262.pdf 